\title{
ACUTE ORAL TOXICITY OF VETOM 21.77 BASED ON DUDDINGTONIA FLAGRANS IN BROILER CHICKENS
}

\author{
Elmira R. Rafikova \\ Department of Pharmacology and General Pathology, Faculty of Veterinary Medicine, \\ Novosibirsk State Agrarian University, 630039 Dobrolubova 160, \\ Novosibirsk, Russian Federation
}

Received 2 March 2018; Received in revised form 12 July 2018; Accepted 18 September 2018

\begin{abstract}
A 14-d study was undertaken to test the acute toxicity of a new preparation Vetom 21.77 based on the predacious fungus Duddingtonia flagrans. A total of 40 healthy 5-day-old broiler chickens (Hubbard F15, $100 \pm 5 \mathrm{~g}$ ), that had previously gone through a required 5-days adaptation to the environment, were orally dosed with the drug for 5 consecutive days at different doses, after which their health status was assessed daily up to the end of the experiment. According to the results, no substantial changes in the physiological state of the chickens were detected during the experiment. Internal organs weighing revealed no statistically significant differences between the groups, though weight coefficient values of internal organs of treated chickens slightly exceeded those of the control group. Some haematological parameters were significantly higher in the treatment group, without going beyond reference ranges. All chickens used in the experiment survived the study. The preparation has not produced any toxic effect even at a higher dose $(4000 \mu \mathrm{L} / \mathrm{kg}$ bw/day). It is concluded that Vetom 21.77 pertains to preparations of IV toxicity class.
\end{abstract}

Key words: Vetom 21.77, Duddingtonia flagrans, acute toxicity, Hubbard F15

\section{INTRODUCTION}

Chicken meat is the most popular meat worldwide nowadays. Its global consumption reached about 115 million tons in 2016 (1), and therefore it's a very alarming fact that gastrointestinal diseases in broilers, including necrotic enteritis, viral enteritis, coccidiosis and many others, have become an increasing concern worldwide (2). Meanwhile, investigation of natural supplements for optimization of the intestinal microflora of industrial poultry is quite an active segment in modern scientific research in the field of poultry farming (3). In recent years, fungal substances have been positioned as such agents. For instance,

Corresponding author: Dr. Elmira Rafikova, DVM

E-mail address: pchelka leta@mail.ru

Present address: Department of Pharmacology and General Pathology,

Faculty of Veterinary Medicine, Novosibirsk State Agrarian University,

630039 Dobrolubova 160, Novosibirsk, Russian Federation

Phone: +7 (913) 9582964

Copyright: (C) 2018 Rafikova E. This is an open-access article published under the terms of the Creative Commons Attribution License which permits unrestricted use, distribution, and reproduction in any medium, provided the original author and source are credited.

Competing Interests: The authors have declared that no competing interests exist.

Available Online First: 30 December 2018

Published on: 15 March 2019

https://doi.org/10.2478/macvetrev-2018-0031
Yudiarti et al. (4) report that the dried culture of Chrysonilia crassa added in chickens diet led to duodenal villi development, as well as to reduction of bacteria and fungi in the gastrointestinal tract, although without a positive effect on chicken productivity. A significant characteristic of organic preparations is that their administration does not lead to the drug resistance phenomenon (5).

Fungi are also efficient in the degradation of complex compounds: a number of fungi are able to catalyze the decomposition of the lignocellulosic biomass contained in animal feeds and, consequently, increase the bioavailability of the nutrients (6). Another advantage of fungal substances is also their ability to generate spores; it allows them to maintain a high range of survivability and stability even under adverse conditions (7). In addition, fungi produce $\beta$-glucans which activate immune cells (8).

A number of trials have revealed the high predatory efficacy of preparations based on fungi against a wide range of helminths colonizing the gastrointestinal tract of various species, such as the filamentous fungi Chrysonilia crassa (9) or Arthrobotrys oligospora $(10,11)$. One of these helminthophags is the predatory fungus $D$. flagrans, 
a spore-mycelial biomass of which is contained in Vetom 21.77 and is supposed to antagonize helminths and pathogenic gut microflora.

Research reports indicate positive results of $D$. flagrans administration in various formulations for biological control of such parasites as Haemonchus contortus (12, 13), Teladorsagia circumcincta (14), Angiostrongylus vasorum (15), Strongyloidae (16) and many more. According to some data, D. flagrans has demonstrated enzyme activity, producing serine proteases $(17,18)$. This is an argument in favor of the possibility of fungus to increase the digestibility of farm animal feeds.

However, application rates and possible effects on poultry of preparations based on spore-forming microorganisms of predatory fungi (such as D. flagrans) have been neglected in the past, so this study may be regarded as relevant. It was undertaken in ordert to assess the acute toxicity of microbiotic Vetom 21.77 ('Исследовательский центр', Novosibirsk region, Russian Federation) based on D. flagrans, to study its influence on the physiological state of the chickens, their growth rate and blood count, as well as to examine the possible side effects of the drug and to assign an acute toxic class to it.

\section{MATERIAL AND METHODS}

\section{Animals and experimental design}

A 14-d experiment was conducted in October 2017 at the Veterinary Research Laboratory of Agrotechnopark, Shakarim state University (Semey, Kazakhstan) on the basis of OECD Test No. 423: Acute Oral Toxicity - Acute Toxic Class Method (2001). A total of 40 healthy 5-day-old broiler chickens (Hubbard F15, mean weight $100 \pm 5 \mathrm{~g}$ ), that had previously gone through the required 5-days adaptation to the environment, were allocated to 1 control and 1 experimental groups of 20 chickens each. The chickens were housed on poultry bedding. Feed and water were provided ad libitum. The birds were fed with a 'ПК 5-1 Старт' pelleted feed mixture (Крупы Востока, Ust-Kamenogorsk, Kazakhstan), $3150 \mathrm{kCal} / \mathrm{kg}$, containing crude protein (22\%), raw fiber $(8 \%)$ and a number of microelements.

According to the abovementioned method, from day 1 chickens from the test group were administered Vetom 21.77 through the crop for 5 consecutive days at 5, 50, 300, 2000 and $4000 \mu \mathrm{L} / \mathrm{kg}$ bw respectively. The birds were not fed for $4 \mathrm{~h}$ before the procedure and $1-2 \mathrm{~h}$ after it. Vetom 21.77 is a liquid that contains spore-mycelial biomass ( 1 x $\left.10^{9} \mathrm{CFUs} / \mathrm{cm}^{3}\right)$ of D. flagrans (strain F-882) as a basis.
The drug reactions were observed by a veterinarian for $30 \mathrm{~min}$ following the procedure, then every $24 \mathrm{~h}$, for a total of 14 days. Chickens from the control group were not given Vetom 21.77. On day 14, all birds in both groups were humanely slaughtered by decapitation according to GOST 52837-2007 'Slaughter poultry. Specifications' (19) and examined post-mortem with weighing of several internal organs (heart, lungs, kidneys, liver, spleen, intestine, stomach and pancreas) in order to examine the possible adverse effect of the preparation. Effectiveness of the broiler chickens growth was evaluated by European Production Efficiency Factors (EPEF) (20).

$$
\mathrm{EPEF}=\frac{\mathrm{LW}(\mathrm{kg}) \times \mathrm{LA}(\%)}{\mathrm{SA}(\text { days }) \times \mathrm{FCR}(\mathrm{kg})} \times 100,
$$

where: $\mathrm{LW}(\mathrm{kg})=$ Live weight at the end of the rearing period; LA $(\%)=$ Livability (number of birds alive at the end of the rearing period relative to the number of chicks placed); SA (days) = Slaughter age of chicks; FCR $(\mathrm{kg})=$ Cumulative feed intake $(\mathrm{kg}) /$ total weight gain $(\mathrm{kg})$.

Criteria for testing the acute toxicity of Vetom 21.77 were the following: physiological state of birds, mortality rate, safety, growth rate, weight and condition of internal organs, haematological and serum biochemical parameters.

All procedures performed in this study were in adherence with the ethical standards of Shakarim State University of Semey city.

\section{Haematological analysis}

Blood samples were immediately collected from the hearts of slaughtered chickens. Haematological analysis was carried out using an automatic haematological analyzer PCE 90 vet (HTI, USA). Biochemical parameters were determined via a semiautomatic biochemical analyzer Minitecno (ISE S.r.l., Italy) and a semi-automatic biochemical analyzer Stat Fax 3300 (Awareness Technology, USA).

\section{Statistical analysis}

The Mann-Whitney one-tailed U-test was performed to compare the mean values of internal organs weight coefficient, as well as the haematological and biochemical parameters between the groups. All the data were analyzed by means of StatsDirect statistical software, version 3.1.14 (StatsDirect Ltd, UK). Values were presented as mean \pm standard deviation. A value of $p<0.05$ was considered significant. 


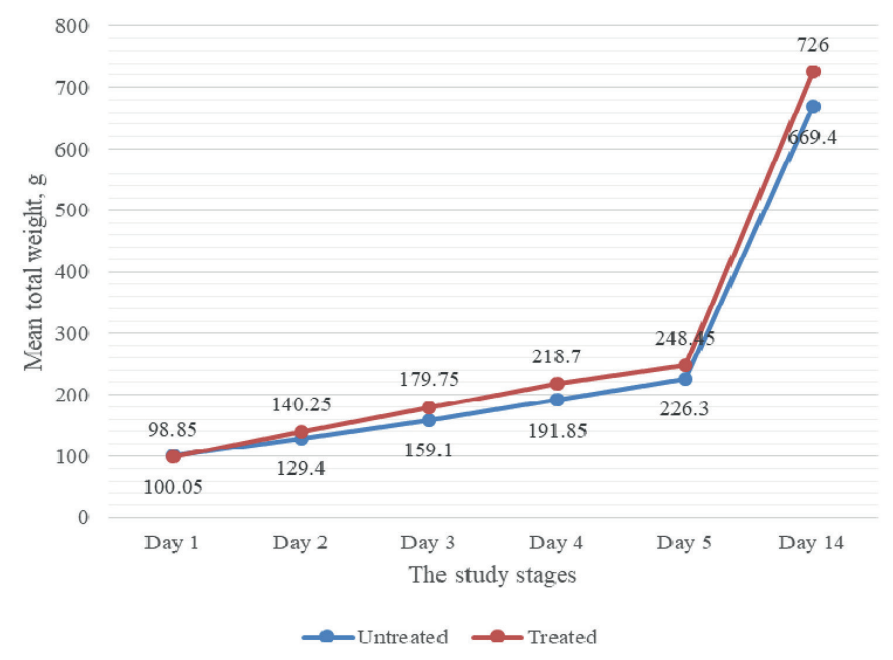

Figure 1. Mean total weight of broiler chickens treated and untreated with Vetom 21.77

\section{RESULTS}

Broiler performances and physiological parameters in both groups before the dosing did not show significant differences: the birds were mobile, with sufficient feed and water uptake; their body weight (bw) was determined as normal. No wounds, redness or alopecia were detected. The skin turgor was normal. The plumage was fluffy, light yellow. Chickens conjunctiva, oral mucosa, genital organs and vent were pink, moist, without visible damage. The beak was yellowish, smooth, without damage. Respiratory rate was normal in both groups: $27-28$ breaths per min (BPM). The average body temperature $\left(\mathrm{t}^{\circ}\right)$ was also within the normal range: $41.7^{\circ} \mathrm{C}$ (control) and $42{ }^{\circ} \mathrm{C}$ (test). The average body weight in the control group was $100.05 \mathrm{~g}$,, while in the test group $-98.85 \mathrm{~g}$, which is $1.2 \%$ lower than the control one.

Within $30 \mathrm{~min}$ after the dosing with Vetom 21.77, no significant changes were observed in the physiological state of the birds in both groups. The average respiratory rate was 27 BPM in the groups. The average body $\mathrm{t}^{\circ}$ was still within the norm: $41.9^{\circ} \mathrm{C}$ (control) and $41.7^{\circ} \mathrm{C}$ (test).

On day 2 , the dose was increased to $50 \mu \mathrm{L} / \mathrm{kg}$ bw. The clinical examinations did not reveal any pathological changes in the physiological state of chickens in both groups; the respiratory rate was left unchanged; the mean body $\mathrm{t}^{\circ}$ was the same in the untreated group, while in the test one $41.8^{\circ} \mathrm{C}$. Treated chickens weighed an average of $140.25 \mathrm{~g}$, controls $-129.4 \mathrm{~g}$. Thus, treated birds' body weight increased $8.4 \%$ higher compared with controls (Fig. 1).
On day 3, when the dose was $300 \mu \mathrm{L} / \mathrm{kg}$ bw, test group chickens were more active and their growth intensity was 13\% ahead of controls (Fig. 1). There were no changes in the respiratory rate in the control group, whilst in the treated group it was $28 \mathrm{BPM}$. The body $\mathrm{t}^{\circ}$ was $41.7^{\circ} \mathrm{C}$ (control) and $41.8^{\circ} \mathrm{C}$ (test).

On day $4(2000 \mu \mathrm{L} / \mathrm{kg} \mathrm{bw})$, all birds were clinically healthy, while feed intake slightly increased in both groups, indicating satisfactory appetite. The respiratory rate was still physiologically normal: 25 BPM (control), 26 BPM (test). The average body $\mathrm{t}^{\circ}$ was $41.8^{\circ} \mathrm{C}$ in both groups. Live weight gain of treated broilers exceeded controls by $14 \%$ (Fig. 1).

On day $5(4000 \mu \mathrm{L} / \mathrm{kg}$ bw), the physiological status of the birds in test and control groups did not differ much. The respiratory rate was $26 \mathrm{BPM}$ in both groups this time. The mean body $\mathrm{t}^{\circ}$ was $41.8^{\circ} \mathrm{C}$ (control) and $41.9^{\circ} \mathrm{C}$ (test). Live weight gain of test group chickens was $9.8 \%$ higher in comparison with controls (Fig. 1).

On day 14 , the absolute mass of treated birds was $8.5 \%$ higher compared with controls (Fig. 1). The respiratory rate was an average of $27 \mathrm{BPM}$ (control) and $26 \mathrm{BPM}$ (test). The mean body $\mathrm{t}^{\circ}$ was $41.8^{\circ} \mathrm{C}$ in both groups. By the end of the experiment, the birds tail feathers have flared.

According to the daily clinical examinations data, the treated birds had adequate appetite; their growth intensity exceeded the control group level. The maximum increase in absolute mass was recorded at $2000 \mu \mathrm{L} / \mathrm{kg}$ bw, day 4 (Fig. 1). No lesions were found in internal organs of the broilers, their weight was slightly more than of those in untreated group (Table 1). 
Table 1. The average weight of body and some internal organs of broiler chickens treated and untreated with Vetom 21.77 at the end of the study (day 14)

\begin{tabular}{lcccc}
\hline \multirow{2}{*}{ Parameters } & \multicolumn{2}{c}{ Control group } & \multicolumn{2}{c}{ Test group } \\
\cline { 2 - 5 } & Weight (g) & Weight coefficient (\%) & Weight (g) & Weight coefficient (\%) \\
\hline Body & $669,40 \pm 34,98$ & - & $726,05 \pm 33,33$ & - \\
Heart & $5,090 \pm 0,508$ & $0,737 \pm 0,038$ & $5,594 \pm 0,519$ & $0,739 \pm 0,043$ \\
Lungs & $2,487 \pm 0,247$ & $0,360 \pm 0,018$ & $2,737 \pm 0,253$ & $0,362 \pm 0,029$ \\
Liver & $22,268 \pm 2,212$ & $3,222 \pm 0,165$ & $24,384 \pm 2,262$ & $3,221 \pm 0,191$ \\
Spleen & $0,666 \pm 0,060$ & $0,096 \pm 0,005$ & $0,735 \pm 0,065$ & $0,097 \pm 0,008$ \\
Kidneys & $3,555 \pm 0,353$ & $0,514 \pm 0,026$ & $3,906 \pm 0,361$ & $0,516 \pm 0,040$ \\
Intestine & $13,812 \pm 1,372$ & $1,999 \pm 0,102$ & $15,123 \pm 1,403$ & $1,998 \pm 0,120$ \\
Stomach & $6,706 \pm 0,667$ & $0,970 \pm 0,050$ & $7,344 \pm 0,681$ & $0,970 \pm 0,058$ \\
Pancreas & $1,310 \pm 0,134$ & $0,190 \pm 0,010$ & $1,443 \pm 0,133$ & $0,191 \pm 0,017$ \\
\hline
\end{tabular}

Values did not differ significantly between the groups at $\mathrm{P}<0.05$

The weight coefficient of some internal organs of the treated birds slightly exceeded those of the control group: heart - by $0.3 \%$, lungs - by $0.5 \%$, spleen - by $0.8 \%$, kidneys - by $0.3 \%$, pancreas - by $0.6 \%$. However, there were no statistically significant differences between the groups (Table 1). EPEF was 40.46 in the control group and 48.29 in the test group $(19.4 \%$ ahead of controls). No morbidity or mortality was registered in any of the Vetom-dosed birds during the experimental period. According to the analysis of hematologic and biochemical parameters, they were within the reference values range in both groups. Besides, erythrocytes and hematocrit values were significantly higher in the treated group (Table 2 and 3 ).

Table 2. Haematological parameters of broiler chickens treated and untreated with Vetom 21.77 at the end of the study (day 14)

\begin{tabular}{lcccc}
\hline Haematological parameters & $\begin{array}{c}\text { Control group } \\
(\mathbf{n = 2 0})\end{array}$ & $\begin{array}{c}\text { Test group } \\
(\mathbf{n = 2 0})\end{array}$ & Reference ranges & P value \\
\hline Erythrocytes $\left(\mathbf{1 0}^{\mathbf{1 2}} / \mathbf{L}\right)$ & $2.65 \pm 0.13$ & $2.72 \pm 0.12$ & $2.5-3.5$ & 0.0381 \\
Leukocytes (10\%/L) & $22.03 \pm 0.53$ & $22.16 \pm 0.59$ & $20-40$ & 0.1844 \\
Platelets (g/L) & $58.28 \pm 4.05$ & $60.07 \pm 3.23$ & $32-100$ & 0.0628 \\
Hematocrit (\%) & $25.95 \pm 1.10$ & $26.70 \pm 1.45$ & $22-35$ & 0.0452 \\
Hemoglobin (g/L) & $99.73 \pm 5.16$ & $102.38 \pm 6.76$ & $70-130$ & 0.0994 \\
MCH (pg) & $37.73 \pm 2.58$ & $37.78 \pm 3.28$ & $33-47$ & 0.369 \\
Lymphocytes (\%) & $53.75 \pm 1.65$ & $54.55 \pm 1.96$ & $52-60$ & 0.0961 \\
Monocytes (\%) & $5.10 \pm 0.72$ & $5.70 \pm 1.56$ & $4-10$ & 0.1622 \\
\hline
\end{tabular}

$\mathrm{MCH}=$ Mean corpuscular hemoglobin

Table 3. Biochemical parameters of broiler chickens treated and untreated with Vetom 21.77 at the end of the study (day 14)

\begin{tabular}{lcccc}
\hline Biochemical parameters & $\begin{array}{c}\text { Control group } \\
(\mathbf{n}=\mathbf{2 0})\end{array}$ & $\begin{array}{c}\text { Test group } \\
(\mathbf{n = 2 0})\end{array}$ & Reference ranges & P value \\
\hline Total protein (g/L) & $35.4 \pm 3.42$ & $37 \pm 3.17$ & $30-44$ & 0.0578 \\
Albumin (g/L) & $20.0 \pm 2.58$ & $21.2 \pm 2.24$ & $14-29$ & 0.0698 \\
Urea (mmol/L) & $0.75 \pm 0.23$ & $0.87 \pm 0.26$ & $0.26-2.04$ & 0.0902 \\
ALT (IU/L) & $7.2 \pm 0.99$ & $7.0 \pm 0.92$ & $0.1-14.8$ & 0.7311 \\
AST (IU/L) & $145.1 \pm 10.49$ & $149.7 \pm 11.53$ & $125-269$ & 0.1221 \\
Phosphorus (mmol/L) & $1.58 \pm 0.19$ & $1.64 \pm 0.15$ & $1.22-3.9$ & 0.0827 \\
Calcium (mmol/L) & $4.03 \pm 0.29$ & $4.18 \pm 0.33$ & $3.75-6.75$ & 0.0746 \\
Total cholesterol (mmol/L) & $3.86 \pm 0.31$ & $3.72 \pm 0.51$ & $2.3-5.5$ & 0.851 \\
\hline
\end{tabular}

ALT $=$ Alanine Aminotransferease. AST $=$ Aspartate Aminotransferase 


\section{DISCUSSION}

Unfortunately, reports on the acute toxicity of fungi-based preparations in any species are very limited. According to the results of an acute oral toxicity study in rats conducted by the European Food Safety Authority (21), D. flagrans had a very low oral toxicity with $\mathrm{LD} 50>2,000 \mathrm{mg} / \mathrm{kg}$ bw.

Another acute oral toxicity study in rats (22) indicated no toxicological effects of the D. flagrans strain IAH 1297 (5,000 mg/kg bw). The oral LD50 $>5,000 \mathrm{mg} / \mathrm{kg}$ bw was reported. This data is in compliance with the results obtained in the present work. Acute toxicity of some organic feed additives has been studied in broilers, where successful results were stated $(23,24)$.

As already mentioned, D. flagrans is a widespread biocontrol agent of animal parasites. It can produce large numbers of thick-walled chlamydospores and survive even at high temperatures $\left(50-60^{\circ} \mathrm{C}\right)$ and in hostile environments, such as animal digestive tract (25). It has been verified by the work of Campos et al. (26) where different fungal structures of $D$. flagrans were resistant to the digestive process in goats.

Grønvold et al. (27) affirm the absence of interspecific (bacterial isolates) or intraspecific (isolates of the fungal genera) competition on agar plates with D. flagrans. According to Fitz-Aranda et al. (28), D. flagrans chlamydospores in nutritional pellets maintained their trapping ability against H. contortus larvae regardless of storage time and experimental conditions.

Ahren et al. (29) have found a low level of genetic variation among D. flagrans strains. The authors emphasize that this property reduces possible adaptation of the strains to a specific geographical region. Preliminary studies on effectiveness of Vetom 21.77 have proved its non-toxicity and some growth-stimulating effect on mice (30) and hypoallergenicity in rabbits (31).

\section{CONCLUSION}

The results of the present study indicate that daily dosing of broiler chickens with Vetom 21.77 caused no physiological alterations that could lead to any damage. According to the daily clinical examinations data, the drug has not produced any toxic effects even at higher dose $(4000 \mu \mathrm{L} / \mathrm{kg} \mathrm{bw})$ in the birds, which classifies this product as non-toxic to broiler chickens. The data presented here have implications for the use of Vetom 21.77 as poultry health promoter.

\section{CONFLICT OF INTEREST}

The authors declared that they have no potential conflict of interest with respect to the authorship and/or publication of this article.

\section{ACKNOWLEDGEMENTS}

The author is grateful to her scientific supervisor, Professor G. A. Nozdrin, for his remarkable guidance and assistance throughout this work. I would like to express my deepest appreciation to Sergey Kozhevnikov for Russian to English translation. I also acknowledge the efforts of the entire team of Veterinary Research Laboratory of Agrotechnopark at Shakarim state University.

\section{REFERENCES}

1. Wang, H., Qi, J., Duan, D., Dong, Y., Xu, X., Zhou, G. (2018). Combination of a novel designed spray cabinet and electrolyzed water to reduce microorganisms on chicken carcasses. Food Control 86, 200-206.

https://doi.org/10.1016/j.foodcont.2017.11.027

2. Mot, D., Timbermont, L., Haesebrouck, F., Ducatelle, R., Van Immerseel, F. (2014). Progress and problems in vaccination against necrotic enteritis in broiler chickens. Avian Pathol. 43(4): 290-300. https://doi.org/10.1080/03079457.2014.939942 PMid:24980518

3. Kim, Y-J., Bostami, A.B.M., Islam, M.M., Mun, H.S., Ko, S.Y., Yang, C-J. (2016). Effect of fermented Ginkgo biloba and Camelia sinensisbased probiotics on growth performance, immunity and caecal microbiology in broilers. Int J Poult Sci. 15(2): 62-71.

https://doi.org/10.3923/ijps.2016.62.71

4. Yudiarti, T., Yunianto, B.I., Murwani, R., Kusdiyantini, E. (2012). The effect of Chrysonilia crassa additive on duodenal and caecal morphology, bacterial and fungal number, and productivity of Ayam Kampung. Int J Sci Eng. 3(2): 26-29.

https://doi.org/10.12777/ijse.3.2.26-29

5. Godfrey, R. W., Dodson, R. E. (2008). Alternative methods of controlling parasites in small ruminants. In: T. Morris, M. Keilty (Eds.), Alternative health practices for livestock (pp. 62-70). Hoboken: WileyBlackwell.

6. Kazda, M., Langer, S., Bengelsdorf, F.R. (2014). Fungi open new possibilities for anaerobic fermentation of organic residues. Energy Substain Soc. 4 (1): 6. https://doi.org/10.1186/2192-0567-4-6 
7. Sugiharto, S., Yudiarti, T., Isroli, I. (2015). Functional properties of filamentous fungi isolated from the Indonesian fermented dried cassava, with particular application on poultry. Mycobiol. 43 (4): 415-422. https://doi.org/10.5941/MYCO.2015.43.4.415 PMid:26839501 PMCid:PMC4731646

8. Kim, H.S., Hong, J.T., Kim, Y., Han, S.B. (2011). Stimulatory effect of $\beta$-glucans on immune cells. Immune Netw. 11(4): 191-195.

https://doi.org/10.4110/in.2011.11.4.191

PMid:22039366 PMCid:PMC3202617

9. Sugiharto, S., Yudiarti, T., Isroli, I., Widiastuti, E., Putra, F.D. (2017). Effect of dietary supplementation with Rhizopus oryzae or Chrysonilia crassa on growth performance, blood profile, intestinal microbial population, and carcass traits in broilers exposed to heat stress. Arch Anim Breed. 60 (3): 347. https://doi.org/10.5194/aab-60-347-2017

10. Flores-Crespo, J., Herrera-Rodríguez, D., Mendoza de Gives, P., Liébano-Hernández, E., Vázquez-Prats, V., López-Arellano, M. (2003). The predatory capability of three nematophagous fungi in the control of Haemonchus contortus infective larvae in ovine faeces. J Helminthol. 77 (4): 297-303. https://doi.org/10.1079/JOH2003197 PMid:14627445

11. Nicola, L., Tosi, S., Savini, D. (2014). In vitro evaluation of nematophagous activity of fungal isolates. J Basic Microbiol. 54(1): 1-5.

https://doi.org/10.1002/jobm.201200431 PMid:23553775

12. Pe-a, M.T., Miller, J.E., Fontenot, M.E., Gillespie, A., Larsen, M. (2002). Evaluation of Duddingtonia flagrans in reducing infective larvae of Haemonchus contortus in feces of sheep. Vet Parasitol. 103 (3): 259-265.

https://doi.org/10.1016/S0304-4017(01)00593-3

13. Aguilar-Marcelino, L., Mendoza-de-Gives, P., Torres-Hernández, G., López-Arellano, M.E., Becerril-Pérez, C.M., Orihuela-Trujillo, A., Olmedo-Juárez, A. (2017). Consumption of nutritional pellets with Duddingtonia flagrans fungal chlamydospores reduces infective nematode larvae of Haemonchus contortus in faeces of Saint Croix lambs. J Helminthol. 91(6): 665-671. https://doi.org/10.1017/S0022149X1600081X PMid:27866480

14. Mendoza-De Gives, P., Zapata, N.C., Hernández, E.L., Arellano, M.E., Rodríguez, D.H., Gardu-o, R.G. (2006). Biological control of gastrointestinal parasitic nematodes using Duddingtonia flagrans in sheep under natural conditions in Mexico. Ann NY Acad Sci. 1081(1): 355-359.

https://doi.org/10.1196/annals.1373.050 PMid:17135538
15. Braga, F.R., Araujo, J.M., Araújo, J.V., Soares, F.E.F., Tavela, A.O., Frassy, L.N., Lima, W.S., Mozzer, L.R. (2013). In vitro predatory activity of conidia of fungal isolates of the Duddingtonia flagrans on Angiostrongylus vasorum first-stage larvae. Rev Soc Bras Med Trop. 46(108): 108-110. https://doi.org/10.1590/0037-86829612013 PMid:23563838

16. Zarrin, M., Rahdar, M., Poormohamadi, F., Rezaei-Matehkolaei, A. (2017). In vitro nematophagous activity of predatory fungi on infective nematodes larval stage of Strongyloidae family. Open Access Maced J Med Sci. 5(3): 281-284. https://doi.org/10.3889/oamjms.2017.064

17. Meyer, W.J., Wiebe, M.G. (2003). Enzyme production by the nematode-trapping fungus, Duddingtonia flagrans. Biotechnol Lett. 25(10): 791-795. https://doi.org/10.1023/A:1023580621840 PMid:12882009

18. Braga, F.R., Araújo, J.V., Soares, F.E.F., Araujo, J.M., Tavela, A.O., de Carvalho, L.M., Mello, I.N.K., Paula, A.T., Queiroz, J.H. (2013). Interaction of the nematophagous fungus Duddingtonia flagrans on Amblyomma cajannense engorged females and enzymatic characterisation of its chitinase. Biocontrol Sci Technol. 23(5): 584-594. https://doi.org/10.1080/09583157.2013.789481

19. GOST 52837-2007 [Internet]. Russian Federation (RU): the Russian Federal Agency for Technical Regulation and Metrology [cited 2018 Aug 24]. http://www.gostrf.com/ normadata/1/4293835/4293835128.pdf

20. Marcu, A., Vacaru-Opriş, I., Dumitrescu, G., Ciochina, L.P., Marcu, A., Nicula, M., Kelciov, B. (2013). The influence of the genotype on economic efficiency of broiler chickens growth. Sci Pap Anim Sci Biotech. 46(2): 339-346.

21. European Food Safety Authority (EFSA). (2006). Opinion of the Panel on additives and products or substances used in animal feed (FEEDAP) on the safety of the micro-organism preparation of Duddingtonia flagrans, for use as a feed additive for calves in accordance with Council Directive 70/524/ EEC. EFSA J. 4(3): 334.

https://doi.org/10.2903/j.efsa.2006.334

22. Healey K, Lawlor C, Knox MR, inventors; International Animal Health Products Pty Ltd., assignee. Composition comprising duddingtonia flagrans. Australian patent WO2018023151A1. 2018 Feb 8.

23. Hashemi, S.R., Idrus, Z., Bejo, M.H., Faridah, A., Somchit M.N. (2008). Acute toxicity study and phytochemical screening of selected herbal aqueous extract in broiler chickens. Int J Pharmacol. 4(5): 352-360. https://doi.org/10.3923/ijp.2008.352.360 
24. Haas, J., Baungratz, A., Takahashi, S., Potrich, M., Lozano, E., Mazaro, S. (2017). Toxicity assessment of insecticidal plants to chicken. Rev Bras Pl Med. 19(2): 190-196.

25. Wang, B.B., Liu, W., Chen, M.Y., Li, X., Han, Y., $\mathrm{Xu}, \mathrm{Q}$., Liu, J.L. (2015). Isolation and characterization of China isolates of Duddingtonia flagrans, a candidate of the nematophagous fungi for biocontrol of animal parasitic nematodes. Journal Parasitol. 101(4): 476-484.

https://doi.org/10.1645/14-715.1

PMid:25978186

26. Campos, A.K., Araújo, J.V., Guimarães, M.P., Dias, A.S. (2009). Resistance of different fungal structures of Duddingtonia flagrans to the digestive process and predatory ability on larvae of Haemonchus contortus and Strongyloides papillosus in goat feces. Parasitol Res. 105(4): 913-919.

https://doi.org/10.1007/s00436-009-1476-Z

PMid:19471967

27. Grønvold, J., Wolstrup, J., Larsen, M., Gillespie, A., Giacomazzi, F. (2004). Interspecific competition between the nematode-trapping fungus, Duddingtonia flagrans, and selected microorganisms and the effect of spore concentration on the efficacy of nematode trapping. J Helminthol. 78(1): 41-46. https://doi.org/10.1079/JOH2003195

PMid:14972035
28. Fitz-Aranda, J., Mendoza-de-Gives, P., Torres-Acosta, J., Liébano-Hernández, E., López-Arellano, M., Sandoval-Castro, C., Quiroz-Romero, H. (2015). Duddingtonia flagrans chlamydospores in nutritional pellets: Effect of storage time and conditions on the trapping ability against Haemonchus contortus larvae. J Helminthol. 89(1): 13-18. https://doi.org/10.1017/S0022149X13000539 PMid:23953994

29. Ahren, D., Faedo, M., Rajashekar, B., Tunlid, A. (2004). Low genetic diversity among isolates of the nematode-trapping fungus Duddingtonia flagrans: evidence for recent worldwide dispersion from a single common ancestor. Mycol Res. 108(10): 12051214.

https://doi.org/10.1017/S0953756204000942 PMid:15535071

30. Rafikova, E.R., Nozdrin, G.A. (2017). A preliminary investigation on determination of a toxicity class of a new probiotic preparation vetom 21.77. Vet Zoot Biot. 9, 51-55.

31. Nozdrin, G.A., Rafikova, E.R. (2017). Evaluation of allergic effect of a new probiotic preparation vetom 21.77. Adv Agric Biol Sci. 3(4): 35-39. https://doi.org/10.22406/aabs-17-3.4-35-39 